\title{
SISTEM PENDUKUNG KEPUTUSAN PEMILIHAN KARYAWAN TELADAN DI UNIVERSITAS BANTEN JAYA MENGGUNAKAN METODE SIMPLE ADDITIVE WEIGHTING (SAW)
}

\author{
Raden Kania ${ }^{1}$, Rustam Effendy ${ }^{2}$, Anggun Risdiansyah ${ }^{3}$ \\ ${ }^{2,3}$ Program Studi Teknik Informatika, ${ }^{1}$ Program Studi Komputerisasi Akuntansi \\ Fakultas Ilmu Komputer, Universitas Banten Jaya Serang \\ Jl Syech Nawawi Albantani Kp. Boru, Kec. Curug, Kota Serang, Banten \\ E-mail: kania@unbaja.ac.id ${ }^{1}$, rustameffendy@unbaja.ac.id ${ }^{2}$, \\ anggunrisdiansyah9@gmail.com
}

\begin{abstract}
Banten Jaya University (UNBAJA) is one of the educational institutions engaged in technology and information, which part of the system has been computerized. But in development there is still a work system that is done manually. Data processing from information that is done manually can be said to be far from the goal, given the importance of effectiveness and efficiency of employee performance. Therefore, Banten Jaya University must be able to improve the quality and quality of employee performance by holding a Decision Support System using the simple addinue weight (SAW) method, which is a computer-based information system and also includes a system with a knowledge management basis, used to support decision making in an organization or company. The decision support system for selecting exemplary employees at the University of Banten Jaya (UNBAJA) can be run well. The development model used is Waterfall. The stage of the process of making a decision support system for selecting exemplary employees at the University of Banten Jaya (UNBAJA) begins with making a design, determining the flow of the work system, making a coding program, making a design view. The decision support system for selecting exemplary employees at the University of Banten Jaya (UNBAJA) uses a PHP MySQL database server. From the test results using the Black Box, the results show that the system testing decision support system for selecting exemplary employees at the University of Banten Jaya (UNBAJA) is successful and can be used and operated well.
\end{abstract}

Keywords: Decision Support Systems, Selection of Exemplary Employees, Simple Additive Weighting.

\section{PENDAHULUAN}

Perkembangan teknologi pada saat ini sangatlah pesat, dapat di lihat dari kemajuan sebuah teknologi informasi dan teknologi yang lain semakin banyak berkembang dan canggih. Kemajuan teknologi informasi semakin berkembang dalam segala aspek kehidupan yang pada penerapannya dapat mempermudah pekerjaan manusia. Penggunaan komputer pada era ini merupakan mayoritas, tidak seperti era dahulu yang tidak semua 
orang memiliki komputer dan itu berbanding terbalik di zaman sekarang. Dengan pesatnya teknologi maka dibutuhkannya suatu sistem, metodologi, strategi, dan perangkat lunak untuk membantu kegiatan organisasi, perusahaan maupun lembaga-lembaga pendidikan.

Sumber Daya Manusia (SDM) merupakan suatu hal yang sangat penting dan harus dimiliki dalam upaya mencapai tujuan organisasi suatu instansi. Sumber Daya Manusia (SDM) juga merupakan asset perusahaan yang paling mahal dibanding dengan aset-aset lain karena Sumber Daya Manusi (SDM) merupakan penggerak utama organisasi perusahaan. Dalam suatu instansi elemen pendukung yang sangat penting salah satunya adalah Sumber Daya Manusia (SDM). Pengelolaan SDM dari suatu instansi sangat mempengaruhi banyak aspek penentu keberhasilan kerja dari instansi tersebut. Jika Sumber Daya Manusi (SDM) dapat diorganisir dengan baik, maka diharapkan instansi dapat menjalankan semua proses usahanya dengan baik.

Universitas Banten Jaya (UNBAJA) merupakan salah satu lembaga pendidikan yang bergerak dalam bidang teknologi dan informasi yang sebagian sistemnya telah terkomputerisasi. Untuk menunjang kinerja yang semakin baik pada semua karyawan serta menghasilkan Sumber Daya Manusia (SDM) yang unggul di Universitas Banten Jaya, untuk itu setiap tahunnya selalu diadakan pemilihan karyawan teladan. Dalam pemilihan karyawan teladan di Universitas Banten Jaya (UNBAJA) ada beberapa kretiria yang sudah di buat dan menjadi patokan dalam pemilihan keryawan teladan. Namun dalam pengembangan masih juga terdapat sistem kerja yang di lakukan secara manual. Pengolahan data dari informasi yang dilakukan secara manual dapat dikatakan masih jauh dari tujuan, mengingat pentingnya keefektifan dan efisiensi kinerja karyawan. Dari tujuan itu maka Universitas Banten Jaya harus mampu meningkatkan kuaitas dan mutu pendidikan yang di selenggarakan. Sistem Pendukung Keputusan (SPK) merupakan sistem informasi berbasis komputer dan juga termasuk sistem dengan basis manajemen pengetahuan, digunakan untuk mendukung pengambilan keputusan pada suatu organisasi atau perusahaan.

Sistem Pendukung Keputusan dalam hal ini bukan alat pengambilan keputusan, melainkan sistem yang dapat membantu pengambil keputusan guna melengkapi informasi data yang diolah secara relevan dan diperlukan untuk membuat keputusan terhadap suatu masalah dengan lebih cepat dan akurat. Sistem ini tidak untuk menggantikan pengambilan keputusan pada proses pembuatan keputusan. SPK memiliki beberapa fungsi yaitu untuk meningkatkan kemampuan para pengambil keputusan dengan memberikan alternatif-alternatif keputusan yang lebih baik, membantu merumuskan masalah dan keadaan yang sedang dihadapi. Selain itu SPK juga dapat meningkatkan 
efektivitas dan efesiensi pengambilan keputusan dan menghemat biaya, waktu, serta tenaga. Terdapat beberapa metode Sistem Pengambil Keputusan, salah satunya adalah metode Simple Addictive Weighting (SAW). Metode SAW yang sering dikenal dengan metode penjumlahan terbobot, memiliki beberapa kelebihan dibandingkan dengan metode lainnya. Metode ini sangat relevan untuk menyelesaikan masalah didalam pengambilan keputusan sering juga disebut sebagai metode penjumlahan terbobot dengan mencari reting setiap alternative. (Nasri \& Kania, 2019).

Berdasarkan pemaparan yang telah disampaikan di atas maka saya tertarik untuk merancang suatu Aplikasi Sistem Pendukung Keputusan Pemilihan Karyawan Teladan Di Universitas Banten Jaya menggunakan Metode Simple Additive Weighting (SAW).

\section{TINJAUAN PUSTAKA}

Sumber Daya Manusia (SDM) merupakan suatu hal yang sangat penting dan harus dimiliki dalam upaya mencapai tujuan organisasi atau perusahaan. (Ambarita, 2012) Dalam (Agusta \& Sutanto, 2013). Pengertian SDM dapat dibagi menjadi dua, yaitu pengertian mikro dan makro. Pengertian SDM secara mikro adalah individu yang bekerja dan menjadi anggota suatu perusahaan atau institusi dan biasa, sedangkan pengertian SDM secara makro adalah penduduk suatu negara yang sudah memasuki usia angkatan kerja.(Susan, 2019)

Sistem pendukung keputusan (SPK) adalah bagian dari sistem informasi berbasis komputer termasuk sistem berbasis pengetahuan atau manajemen pengetahuan yang dipakai untuk mendukung pengambilan keputusan dalam suatu organisasi atau perusahaan. (Ching-Chin ,dkk.: 2010) dalam (Achmad \& Solichin, 2018). Sistem pendukung keputusan (SPK) biasanya di bangun tuntuk mendukung solusi atas suatu masalah atau untuk suatau peluang. (Nofriansyah, 2015)

Metode Simple Additive Weighting (SAW) merupakan metode penjumlahan terbobot. Konsep dasar metode ini adalah mencari penjumlahan terbobot dari rating kinerja pada setiap alternatif pada semua kriteria (Rinaldhi, G. E. : 2013) dalam (Fauzan et al., 2018). Metode simple Additive Weighting (SAW) dijadikan contoh perhitungan yang dipilih paling baik karena metode ini bisa menentukan alternatif setiap atributnya. Kemudian ditahap selanjutnya dibuat perankingan yang akan memilih alternatif terbaik. Metode simple additive weighting (SAW) dapat diartikan sebagai sistem penjumlahan berbobot. (Limbong \& Iskandar, 
2020). Menurut (Kusumadewi et al., 2016) langkah penyelesaian dalam penggunaannya adalah:

1. Menentukan kriteria yang akan dijadikan acuan dalam pengambilan keputusan, yaitu $\mathrm{Ci}$

2. Memberikan nilai bobot untuk masing-masing kriteria sebagai $\mathrm{W}$.

3. Memberikan nilai rating kecocokan setiap alternatif pada setiap kriteria.

4. Membuat tabel rating kecocokan dari setiap alternatif pada setiap kriteria.

5. Membuat matrik keputusan (X) yang dibentuk dari tabel rating kecocokan dari setiap alternatif pada setiap kriteria. Nilai X setiap alternatif (Ai) pada setiap kriteria $(\mathrm{Cj})$ yang sudah ditentukan, dimana, $i=1,2, \ldots \mathrm{m}$ dan $\mathrm{j}=1,2, \ldots \mathrm{n}$.

$$
X=\left[\begin{array}{cccc}
x_{11} & x_{12} & \ldots & x_{1 j} \\
\cdot & & & \cdot \\
\dot{x_{i 1}} & x_{i 2} & \ldots & x_{i j}
\end{array}\right]
$$

6. Melakukan normalisasi matrik keputusan dengan cara menghitung nilai rating kinerja ternomalisasi (rij) dari alternatif Aipada kriteria $\mathrm{Cj}$.

$$
r_{i j}=\left\{\begin{array}{l}
\frac{x_{i j}}{\operatorname{Max}_{i}\left(x_{i j}\right)} \\
\frac{\operatorname{Min}_{i} x_{i j}}{x_{i j}}
\end{array}\right.
$$

7. Hasil akhir nilai preferensi (Vi) diperoleh dari penjumlahan dari perkalian elemen baris matrik ternormalisasi (R) dengan bobot preferensi (W) yang bersesuaian eleman kolom matrik $(\mathrm{W})$.

$$
V_{i}=\sum_{j=1}^{n} W_{j} r_{i j}
$$

Hasil perhitungan nilai Vi yang lebih besar mengindikasikan bahwa alternatif Vi merupakan alternatif terbaik.

\section{METODOLOGI PENELITIAN}

Penelitian ini menggunakan metode Simple Additive Weighting (SAW) yang dikenal dengan metode penjumlahan terbobot, memiliki beberapa kelebihan dibandingkan dengan metode lainnya. Penelitian ini menggunakan model penelitian Waterfall. Model waterfall adalah alur hidup klasik yang menyediakan 
pendekatan alur hidup perangkat lunak secara sekuensial atau terurut mulai dari analisis, desain, coding, dan pengujian (Shalahudin \& Rosa, 2018) Dalam penelitian ini terdapat tahapan penelitian adalah sebagai berikut :

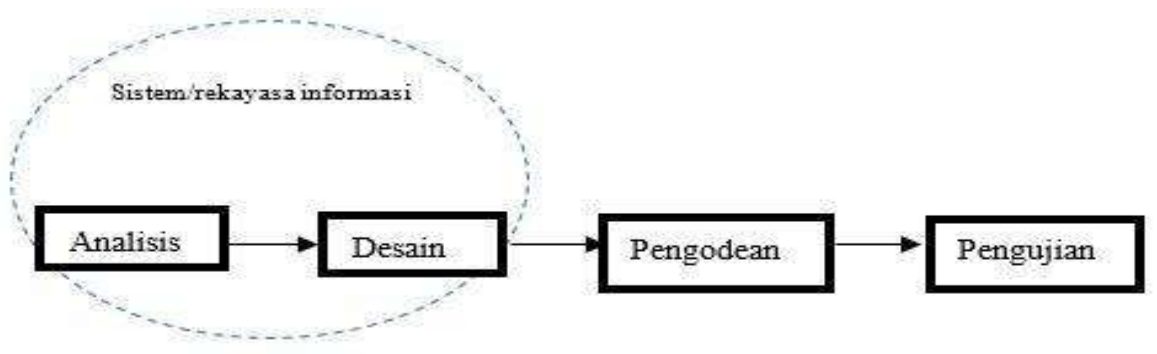

Gambar 1. Ilustrasi Model Waterfall

\section{Analisis}

Analisis bertujuan untuk memahami perangkat lunak yang diharapkan oleh pengguna serta batasan perangkat lunak tersebut. Informasi ini diperoleh melalui observasi dan wawancara. Informasi dianalisis untuk mendapatkan data yang digunakan oleh pengguna. Analisis pada penelitian ini adalah: (1) Analisis sistem berjalan merupakan gambaran mengenai sistem yang saat ini sedang berjalan di Universitas Banten Jaya (UNBAJA). dari hasil observasi yang telah dilakukan, bahwasannya Sistem pemilihan karyawan teladan di Universitas Banten Jaya masih menggunakan sistem manual sehingga mempersulit dalam pengambilan keputusan. (2) Sistem Pendukung Keputusan untuk pemilihan karyawan teladan perlu di rancang sebagai solusi untuk mempermudah dan mempercepat bidang Kepegawaian dalam memilih dan menilai karyawan teladan di Universitas Banten Jaya (UNBAJA), sehingga waktu dan penilaian pun dapat jadi lebih mudah dan singkat. (3) Analisis keluaran bertujuan untuk menganalisa hasil dari proses dan keluaran yang telah di proses oleh system. (4) Analisais Masukan bertujuan untuk menganalisa data masukan yang akan di proses oleh system.

\section{Desain}

Desain perangkat lunak adalah suatu proses multilangkah yang berfokus pada desain dalam pembuatan program termasuk struktur data, arsitektur, representasi dan prosedur pengodean. Tahap ini merupakan mentranslasi dari 
kebutuhan perangkat lunak dari tahap analisis kebutuhan ke representasi desain agar dapat diterapkan menjadi program pada tahap tahap ini dilakukan setelah dilakukan analisis kebutuhan. Desain perangkat yang dihasilkan dibuat menggunakan UML guna membantu mendefinisikan arsitektur system secara keseluruhan juga perlunya didokumentasikan.

Perancangan pemodelan sistem menggunakan Unified Modelling language (UML), usecase diagram yang dibuat dalam penelitian ini adalah sebagai berikut:

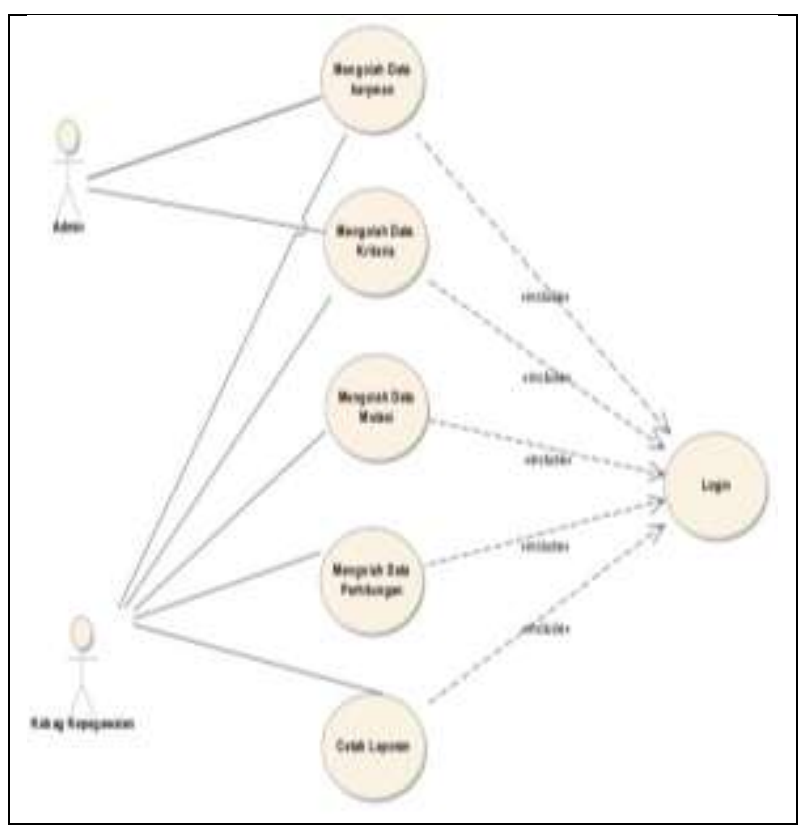

Gambar 2. Usecase Diagram Sistem

\section{Pengkodean}

Pembuatan kode program dimana desain harus di translasikan ke dalam program perangkat lunak. Hasil yang didapat dari tahap ini adalah program komputer sesuai dengan desain yang telah dibuat sebelumnya.

\section{Pengujian}

Pada penelitian ini menggunakan pengujian kelayakan menggunakan blackbox. Pengujian menggunakan blackbox ini menguji kegunaan dari sistem informasi berdasakan keberfungsian dari hasil akhir media.

Berdasarkan rancangan sistem dan database yang telah dibuat, maka pembuatan sistem ini dibuat berdasarkan data-data yang telah diterima selama 
penelitian dan petunjuk-petunjuk yang telah diberikan oleh pembimbing. System yang telah dibuat selanjutnya dilakukan uji coba kepada dosen pembimbing untuk mengetahui kecukupan pada sistem dan kepada Bagian kepegawaian di Universitas Banten Jaya (UNBAJA) untuk didapatkan hasil uji Black Box. Dari hasil uji coba yang telah dilakukan, system yang telah diujikan tidak mengalami hambatan selama pelaksanaan pengujian. Berikut ini merupakan data Black Box hasil uji coba yang telah dilakukan:

Tabel 1. Hasil Uji Black Box

\begin{tabular}{|c|l|l|l|c|}
\hline No & Item Uji & \multicolumn{1}{|c|}{$\begin{array}{c}\text { Detail } \\
\text { Pengujian }\end{array}$} & \multicolumn{1}{|c|}{ Hasil Pengujian } & Kesimpulan \\
\hline 1 & Proses Login & $\begin{array}{l}\text { Menampilkan } \\
\text { form username } \\
\text { dan password }\end{array}$ & $\begin{array}{l}\text { Setelah admin memasukkan } \\
\text { username dan Password } \\
\text { kedalam sistem, maka sistem } \\
\text { akan menampilkan halaman } \\
\text { utama. }\end{array}$ & Berhasil \\
\hline 2 & $\begin{array}{l}\text { Input data } \\
\text { Karyawan }\end{array}$ & $\begin{array}{l}\text { Menampilkan } \\
\text { form input } \\
\text { data karyawan }\end{array}$ & $\begin{array}{l}\text { Setelah admin melakukan } \\
\text { input data karyawan, maka } \\
\text { sistem akan menampilkan } \\
\text { data karyawan yang } \\
\text { disimpan }\end{array}$ & Berhasil \\
\hline 3 & $\begin{array}{l}\text { Input Data } \\
\text { Kriteria }\end{array}$ & $\begin{array}{l}\text { Menampilkan } \\
\text { form input } \\
\text { data kriteria }\end{array}$ & $\begin{array}{l}\text { Setelah admin melakukan } \\
\text { input data kriteria, maka } \\
\text { sistem akan menampilkan } \\
\text { data kriteria yang disimpan }\end{array}$ & Berhasil \\
\hline Perhitungan & $\begin{array}{l}\text { Menampilkan } \\
\text { data } \\
\text { perhitungan }\end{array}$ & $\begin{array}{l}\text { Setelah admin melakukan } \\
\text { perhitungan, maka system } \\
\text { akan menampilkan hasil } \\
\text { perhitungan }\end{array}$ & Berhasil \\
\hline 5 & $\begin{array}{l}\text { Cetak Hasil } \\
\text { Laporan }\end{array}$ & $\begin{array}{l}\text { Menampilkan } \\
\text { hasil } \\
\text { pemilihan } \\
\text { karyawan }\end{array}$ & $\begin{array}{l}\text { System akan menampilkan } \\
\text { laporan hasil pemilihan } \\
\text { karyawan teladan }\end{array}$ & Berhasil \\
\hline
\end{tabular}

Selanjutnya dilakukan Pegujian Perhitungan Simple Additive Weight (SAW).

Langkah langkah untuk menetukan perhitungan untuk pemilihan karyawan teladan menggunakan metode Simple Additive Weighting (SAW), yaitu:

Langkah kesatu (1) menentukan kriteria yang akan digunakan sebagai acuan dalam pemilihan karyawan teladan yaitu $\mathrm{C}_{\mathrm{i}}$. 
Tabel 2. Tabel Ketentuan Kriteria

\begin{tabular}{|c|c|}
\hline Kode Kriteria $\left(\mathrm{C}_{\mathrm{i}}\right)$ & Ketentuan Kriteria \\
\hline $\mathrm{C}_{1}$ & Perilaku \\
\hline $\mathrm{C}_{2}$ & Kerjasama Tim \\
\hline $\mathrm{C}_{3}$ & Kehadiran \\
\hline $\mathrm{C}_{4}$ & Produktifitas \\
\hline
\end{tabular}

Langkah kedua (2) memberikan nilai bobot atau setiap kriteria. Bobot kriteria yang akan di gunakan dalam memilih karyawan teladan adalah sebagai berikut:

Tabel 3. Tabel Bobot Setiap Kriteria

\begin{tabular}{|c|c|c|}
\hline Kode Kriteria & Ketentuan Kriteria & Bobot Preferensi (W) \\
\hline $\mathrm{C}_{1}$ & Perilaku & $0,30(30 \%)$ \\
\hline $\mathrm{C}_{2}$ & Kerjasama Tim & $0,15(15 \%)$ \\
\hline $\mathrm{C}_{3}$ & Kehadiran & $0,30(30 \%)$ \\
\hline $\mathrm{C}_{4}$ & Produktifitas & $0,25(25 \%)$ \\
\hline
\end{tabular}

Langkah ketiga (3) menentukan rating setiap alternatif pada setiap kriteria.

Tabel 4.Tabel Rating dari Setiap Alternatif pada Setiap Kriteria

\begin{tabular}{|c|c|c|c|c|}
\hline \multirow{2}{*}{ Alternatif } & \multicolumn{4}{|c|}{ Kriteria } \\
\cline { 2 - 5 } & $\mathrm{C}_{1}$ & $\mathrm{C}_{2}$ & $\mathrm{C}_{3}$ & $\mathrm{C}_{4}$ \\
\hline $\mathrm{A}_{1}$ & 90 & 100 & 60 & 70 \\
\hline $\mathrm{A}_{2}$ & 80 & 90 & 100 & 90 \\
\hline $\mathrm{A}_{3}$ & 90 & 50 & 50 & 80 \\
\hline $\mathrm{A}_{4}$ & 70 & 60 & 90 & 90 \\
\hline $\mathrm{A}_{5}$ & 90 & 100 & 80 & 80 \\
\hline $\mathrm{A}_{6}$ & 80 & 50 & 80 & 90 \\
\hline $\mathrm{A}_{7}$ & 90 & 90 & 90 & 100 \\
\hline $\mathrm{A}_{8}$ & 80 & 80 & 80 & 60 \\
\hline $\mathrm{A}_{9}$ & 90 & 90 & 90 & 70 \\
\hline $\mathrm{A}_{10}$ & 100 & 70 & 100 & 70 \\
\hline $\mathrm{A}_{11}$ & 70 & 90 & 60 & 90 \\
\hline $\mathrm{A}_{12}$ & 50 & 80 & 70 & 80 \\
\hline $\mathrm{A}_{13}$ & 60 & 90 & 70 & 90 \\
\hline $\mathrm{A}_{14}$ & 90 & 80 & 90 & 80 \\
\hline $\mathrm{A}_{15}$ & 50 & 90 & 100 & 90 \\
\hline $\mathrm{A}_{16}$ & 90 & 100 & 70 & 100 \\
\hline $\mathrm{A}_{17}$ & 80 & 60 & 50 & 60 \\
\hline $\mathrm{A}_{18}$ & 90 & 70 & 60 & 70 \\
\hline $\mathrm{A}_{19}$ & 90 & 70 & 100 & 70 \\
\hline $\mathrm{A}_{20}$ & 100 & 80 & 50 & 80 \\
\hline & & & & \\
\hline
\end{tabular}


Setelah nilai rating alternatif pada setiap kriteria ditentukan langkah keempat (4) adalah pembentukan proses normalisasi (X) yang dibentuk dari tabel rating dari setiap alternatif pada setiap kriteria. Hasil dari proses normalisasi keputusan berdasarkan perhitungan kriteria. Digambarkan dalam bentuk tabel sebagai berikut:

Tabel 5. Proses normalisasi

\begin{tabular}{|c|l|c|c|c|c|}
\hline \multirow{2}{*}{ No } & \multirow{2}{*}{ Nama Karyawan } & \multicolumn{4}{|c|}{ Kriteria } \\
\cline { 2 - 5 } & Kedisiplinan & $\begin{array}{c}\text { Kerjasama } \\
\text { Tim }\end{array}$ & Kehadiran & $\begin{array}{c}\text { Produkti } \\
\text { fitas }\end{array}$ \\
\hline 1 & Junedi, S.Kom & 0,9 & 1 & 0,6 & 0,7 \\
\hline 2 & Iyan Alfian & 0,8 & 0,9 & 1 & 0,9 \\
\hline 3 & Sobari & 0,9 & 0,5 & 0,5 & 0,8 \\
\hline 4 & Irvan Al Asari, S.Kom & 0,7 & 0,6 & 0,9 & 0,9 \\
\hline 5 & Sayuti & 0,9 & 1 & 0,8 & 0,8 \\
\hline 6 & Sukroni & 0,8 & 0,5 & 0,8 & 0,9 \\
\hline 7 & Winda N F, S.Kom & 0,9 & 0,9 & 0,9 & 1 \\
\hline 8 & Sarikam & 0,8 & 0,8 & 0,8 & 0,6 \\
\hline 9 & Nuralela, S.Kom & 0,9 & 0,9 & 0,9 & 0,7 \\
\hline 10 & Anna Rosdiana, S.Kom & 1 & 0,7 & 1 & 0,7 \\
\hline 11 & Duhoni & 0,7 & 0,9 & 0,6 & 0,9 \\
\hline 12 & Rendy Nandika, SE & 0,5 & 0,8 & 0,7 & 0,8 \\
\hline 13 & PamujioDno & 0,6 & 0,9 & 0,7 & 0,9 \\
\hline 14 & Laras Mayang Sari, SPd. & 0.9 & 0,8 & 0,9 & 0,8 \\
\hline 15 & Hamdani, A.Md & 0,5 & 0,9 & 1 & 0,9 \\
\hline 16 & Neshya Faniya & 0,9 & 1 & 0,7 & 1 \\
\hline 17 & Siti Rohmah & 0,8 & 0,6 & 0,5 & 0,6 \\
\hline 18 & Hasanudin & 0,9 & 0,7 & 0,6 & 0,7 \\
\hline 19 & Tanti Rahmawati & 0,9 & 0,7 & 1 & 0,7 \\
\hline 20 & Sri Fitriyah, SP & 1 & 0,8 & 0,5 & 0,8 \\
\hline
\end{tabular}

Hasil dari nilai rating kinerja ternomalisasi (rij) membentuk matrik ternormalisasi (R).

Tabel 6. Hasil rating kinerja ternomalisasi

\begin{tabular}{|c|c|c|c|}
\hline 0,9 & 1 & 0,6 & 0,7 \\
\hline 0,8 & 0,9 & 1 & 0,9 \\
\hline 0,9 & 0,5 & 0,5 & 0,8 \\
\hline 0,7 & 0,6 & 0,9 & 0,9 \\
\hline 0,9 & 1 & 0,8 & 0,8 \\
\hline 0,8 & 0,5 & 0,8 & 0,9 \\
\hline 0,9 & 0,9 & 0,9 & 1 \\
\hline 0,8 & 0,8 & 0,8 & 0,6 \\
\hline 0,9 & 0,9 & 0,9 & 0,7 \\
\hline 1 & 0,7 & 1 & 0,7 \\
\hline 0,7 & 0,9 & 0,6 & 0,9 \\
\hline 0,5 & 0,8 & 0,7 & 0,8 \\
\hline
\end{tabular}




\begin{tabular}{|c|c|c|c|}
\hline 0,6 & 0,9 & 0,7 & 0,9 \\
\hline 0,9 & 0,8 & 0,9 & 0,8 \\
\hline 0,5 & 0,9 & 1 & 0,9 \\
\hline 0,9 & 1 & 0,7 & 1 \\
\hline 0,8 & 0,6 & 0,5 & 0,6 \\
\hline 0,9 & 0,7 & 0,6 & 0,7 \\
\hline 0,9 & 0,7 & 1 & 0,7 \\
\hline 1 & 0,8 & 0,5 & 0,8 \\
\hline
\end{tabular}

Hasil akhir nilai preferensi (Vi) diperoleh dari penjumlahan dari perkalian elemen baris matrik ternormalisasi (R) dengan bobot preferensi (W) yang bersesuaian eleman kolom matrik (W)

$$
\begin{aligned}
& \mathrm{V}_{1}=(0,9)(0,30)+(1)(0,15)+(0,6)(0,30)+(0,7)(0,25) \\
& =0,27+0,15+0,18+0,175=0,775 \\
& \mathrm{~V}_{2}=(0,8)(0,30)+(0,9)(0,15)+(1)(0,30)+(0,9)(0,25) \\
& =0,24+0,135+0,30+0,225=0,9 \\
& \mathrm{~V}_{3}=(0,9)(0,30)+(0,5)(0,15)+(0,5)(0,30)+(0,8)(0,25) \\
& =0,27+0,075+0,15+0,2=0,695 \\
& \mathrm{~V}_{4}=(0,7)(0,30)+(0,6)(0,15)+(0,9)(0,30)+(0,9)(0,25) \\
& =0,21+0,09+0,27+0,225=0,795 \\
& \mathrm{~V}_{5}=(0,9)(0,30)+(1)(0,15)+(0,8)(0,30)+(0,8)(0,25) \\
& =0,27+0,15+0,24+0,2=0,86 \\
& \mathrm{~V}_{6}=(0,8)(0,30)+(0,5)(0,15)+(0,8)(0,30)+(0,9)(0,25) \\
& =0,24+0,075+, .24+0,225=0,78 \\
& \mathrm{~V}_{7}=(0,9)(0,30)+(0,9)(0,15)+(0,9)(0,30)+(1)(0,25) \\
& =0,27+0,135+0,27+0,25=0,925 \\
& \mathrm{~V}_{8}=(0,8)(0,30)+(0,8)(0,15)+(0,8)(0,30)+(0,6)(0,25) \\
& =0,24+0,12+0,24+0,15=0,75 \\
& \mathrm{~V}_{9}=(0,9)(0,30)+(0,9)(0,15)+(0,9)(0,30)+(0,7)(0,25) \\
& =0,27+0,135+0,27+0,175=0,85 \\
& \mathrm{~V}_{10}=(1)(0.30)+(0.7)(0.15)+(1)(0.30)+(0.7)(0.25) \\
& =0.30+0.105+0.30+0.175=0.88 \\
& \mathrm{~V}_{11}=(0,7)(0,30)+(0,9)(0,15)+(0,6)(0,30)+(0,9)(0,25) \\
& =0,21+0,135+0,18+0,225=0,75
\end{aligned}
$$


$\mathrm{V}_{12}=(0,5)(0,30)+(0,8)(0,15)+(0,7)(0,30)+(0,8)(0,25)$

$=0,15+0,12+0,21+0,2=0,68$

$\mathrm{V}_{13}=(0,6)(0,30)+(0,9)(0,15)+(0,7)(0,30)+(0.9)(0,25)$

$=0,18+0,135+0,21+0,225=0,75$

$\mathrm{V}_{14}=(0,9)(0,30)+(0,8)(0,15)+(0,9)(0,30)+(0,8)(0,25)$

$=0,27+0,12+0,27+0,2=0.86$

$\mathrm{V}_{15}=(0,5)(0,30)+(0,9)(0,15)+(1)(0,30)+(0,9)(0,25)$

$=0,15+0,135+0,30+0,225=0,81$

$\mathrm{V}_{16}=(0,9)(0,30)+(1)(0,15)+(0,7)(0,30)+(1)(0,25)$

$=0,27+0,15+0,21+0,25=0,88$

$\mathrm{V}_{17}=(0,8)(0,30)+(0,6)(0,15)+(0,5)(0,30)+(0,6)(0,25)$

$=0,24+0,09+0,15+0,15=0,63$

$\left.\mathrm{V}_{18}=(0,9)(0,30)+(0,7)(0,15)\right)+(0,6)(0,30)+(0,7)(0,25)$

$=0,27+0,105+0,18+0,175=0,73$

$\mathrm{V}_{19}=(0,9)(0,30)+(0,7)(0,15)+(1)(0,30)+(0,7)(0,25)$

$=0,27+0,105+0,30+0,175=0,85$

$\mathrm{V}_{20}=(1)(0,30)+(0,8)(0,15)+(05)(0,30)+(0,8)(0,25)$

$=0,30+0,12+0,15+0,2=0,77$

Semakin tinggi hasil akhir yang diperoleh maka akan semakin besar peluang untuk menjadi karyawan teladan. Berikut hasil perankingan dengan metode Simple Additive Weighting (SAW)

Tabel 7. Tabel Hasil Perankingan

\begin{tabular}{|r|l|c|c|}
\hline No & Nama Karyawan & Hasil Akhir & Ranking \\
\hline 1 & Winda N F, S.Kom & 92,5 & 1 \\
\hline 2 & Iyan Alfian & 90 & 2 \\
\hline 3 & Anna Rosdiana, S.Kom & 88 & 3 \\
\hline 4 & Neshya Faniya & 88 & 4 \\
\hline 5 & Sayuti & 86 & 5 \\
\hline 6 & Laras Mayang Sari, SPd. & 86 & 6 \\
\hline 7 & Nuralela, S.Kom & 85 & 7 \\
\hline 8 & Tanti Rahmawati & 85 & 8 \\
\hline 9 & Hamdani, A.Md & 81 & 9 \\
\hline 10 & Irvan Al Asari, S.Kom & 79.5 & 10 \\
\hline 11 & Sukroni & 78 & 11 \\
\hline 12 & Junedi, S.Kom & 77.5 & 12 \\
\hline 13 & Sri Fitriyah, SP & 77 & 13 \\
\hline 14 & Pamujiono & 75 & 14 \\
\hline 15 & Duhoni & 75 & 15 \\
\hline 16 & Sarikam & 75 & 16 \\
\hline
\end{tabular}




\begin{tabular}{|c|l|c|c|}
\hline 17 & Hasanudin & 73 & 17 \\
\hline 18 & Sobari & 69.5 & 18 \\
\hline 19 & Rendy Nandika, SE & 68 & 19 \\
\hline 20 & Siti Rohmah & 63 & 20 \\
\hline
\end{tabular}

Dari perhitungan yang telah dilakukan dengan menggunakan metode Simple Additive Weighting (SAW) didapatkan hasil yaitu nilai tertinggi pada Winda N F, S.Kom dengan nilai akhir 92.5 dan pada urutan pertama sedangkan nilai terendah pada Siti Rohmah dengan nilai 63 pada urutan ke 20.

\section{HASIL DAN PEMBAHASAN}

Tampilan login memperlihatkan tampilan awal dari menu login sistem.

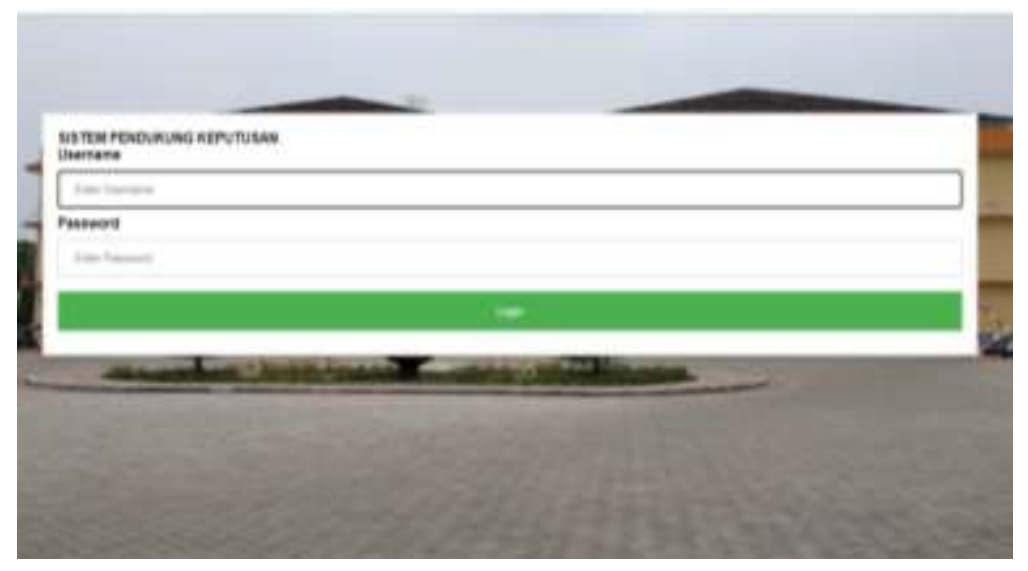

Gambar 3. Tampilan Login

Menu utama / home berfungsi untuk kata sambutan dan memperkenalkan sistem yang sedang berjalan.

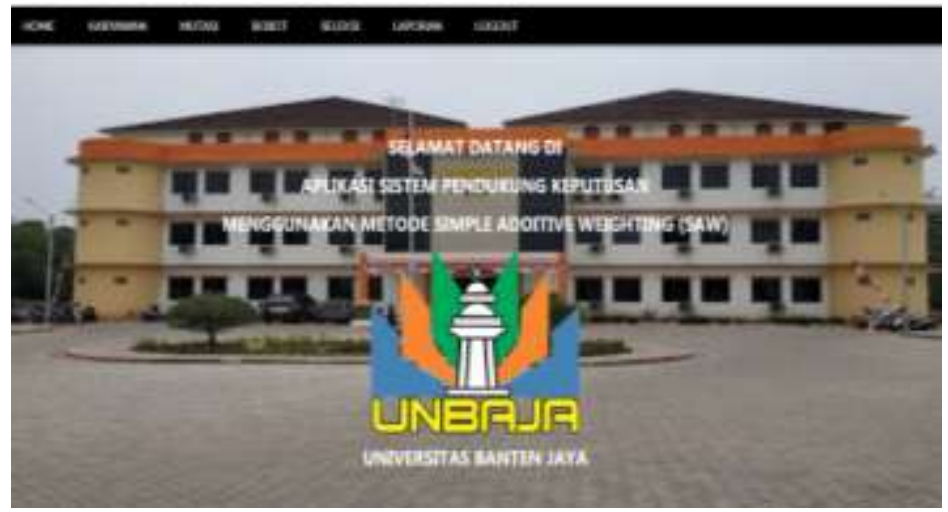

Gambar 4. Tampilan Menu Utama 
Input data karyawan berfungsi untuk menginput dan menambahkan data karyawan yang sudah ada maupun yang baru bergabung pada instansi.

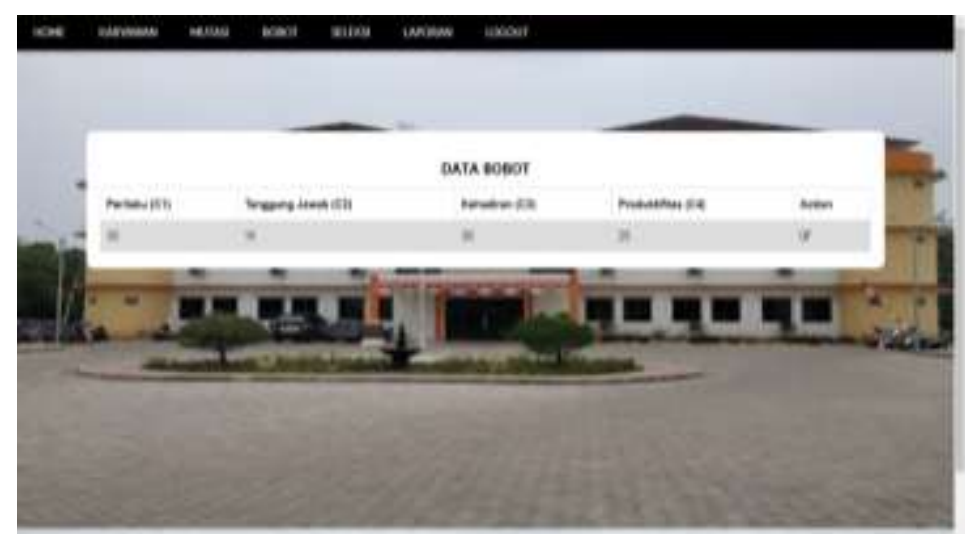

Gambar 5. Tampilan Data Karyawan

Tampilam input data seleksi berfungsi untuk memasukan nilai-nilai kriteria yang sudah ada untuk memulai perhitungan dengan metode SAW.

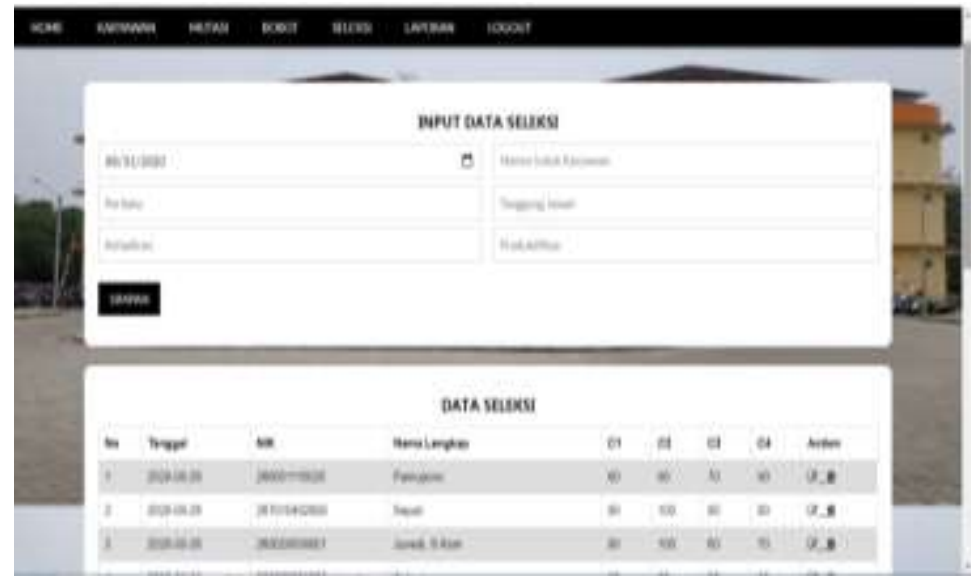

Gambar 6. Tampilan Data Seleksi

Tampilan data bobot merupakan tampila yang berfungsi untuk mengetahui apa saja yang masuk dalam kriteria perhitungan yang di nilai oleh bagian kepegawaian. 


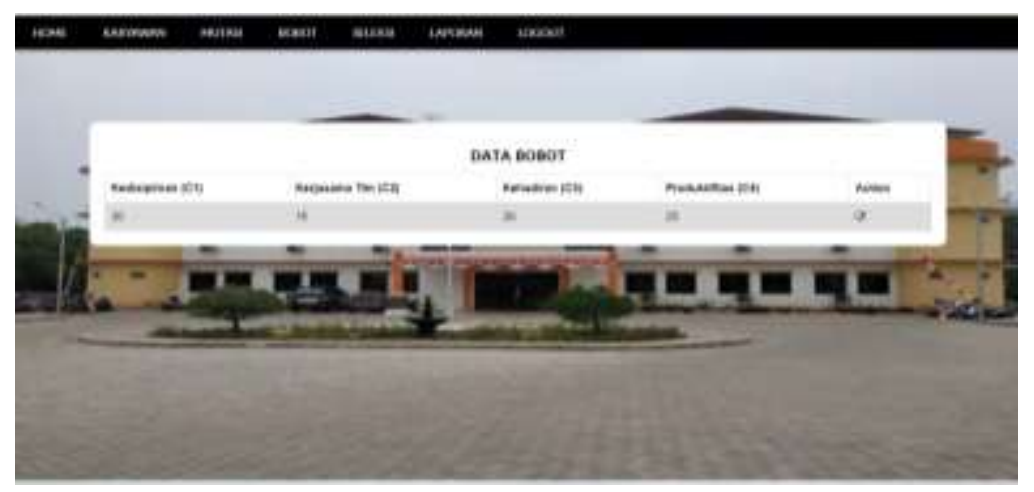

Gambar 7. Tampilan Data Bobot

Tampilan data perhitungan berfungsi untuk mengetahui beberapa karyawan yang masuk dalam penilaian tertinggi dan hasil dari perhitungan yang telah di lakukan.
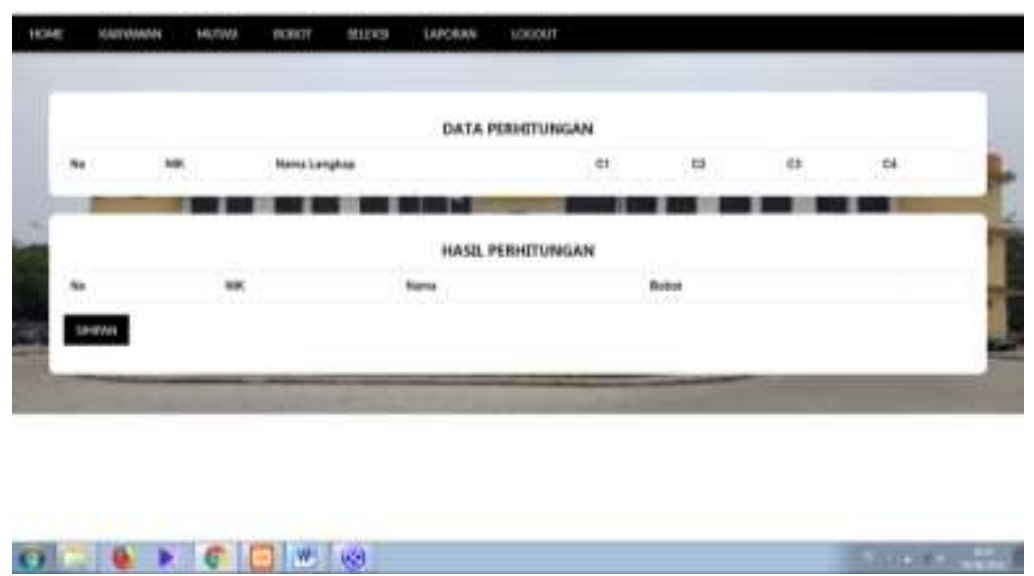

Gambar 8. Tampilan Data Perhitungan

Data laporan berfungsi untuk membuat laporan dan hasil lampiran penilian karyawan yang telah di lakukan pada tiap periodik.

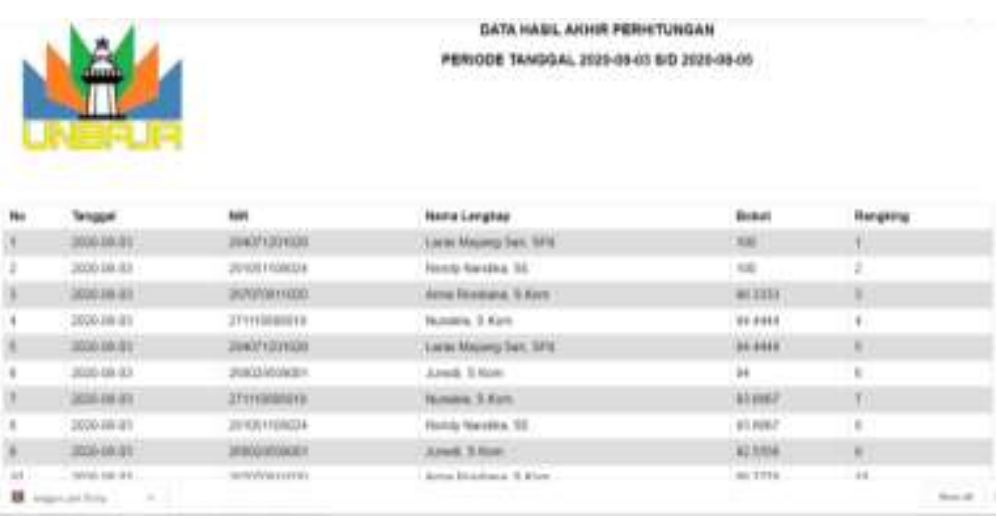

Gambar 9. Tampilan Data Laporan 


\section{KESIMPULAN}

Berdasarkan penelitian Sistem pendukung keputusan pemilihan karyawan teladan di Universitas Banten Jaya (UNBAJA) yang telah dilakukan, maka dapat disimpulkan sebagai berikut:

1. Sistem pendukung keputusan pemilihan karyawan teladan di Universitas Banten Jaya (UNBAJA) dapat dijalankan dengan baik. Model pengembangan yang digunakan yaitu Waterfall. Tahap proses pembuatan Sistem pendukung keputusan pemilihan karyawan teladan di Universitas Banten Jaya (UNBAJA) dimulai dengan pembuatan perancangan, penentuan alur dari sistem kerja, pembuatan program coding, membuat tampilan desain. Sistem Sistem pendukung keputusan pemilihan karyawan teladan di Universitas Banten Jaya (UNBAJA) ini menggunakan database server PHP MySQL.

2. Dari hasil pengujian dengan menggunakan Black Box didapatkan hasil bahwasannya, pengujian Sistem pendukung keputusan pemilihan karyawan teladan di Universitas Banten Jaya (UNBAJA) ini berhasil dan dapat digunakan serta diperasikan dengan baik. Tingkat keberhasilan sampai saat di tes itu mencapai $80-90 \%$ lebih mudah dan efektif di banding dengan perhitungan manual yg sedang berjalan di unbaja bu. Di kepegawaian sendiri masi menggunakan exel

3. Dari perhitungan yang telah dilakukan dengan menggunakan metode Simple Additive Weight (SAW) didaptkan hasilnya yaitu nilai tertinggi pada Winda $\mathrm{N}$ F, S.Kom dengan nilai akhir 92.5 pada urutan pertama sedangkan nilai terendah pada Siti Rohmah dengan nilai 63 pada urutan ke 20. Kalau ada kesamaan data nanti ada notif kalau data sudah di gunakan.

\section{REFERENSI}

Achmad, S., \& Solichin, A. (2018). Prototipe Sistem Pendukung Keputusan untuk Penentuan Guru Teladan pada SMK Era Informatika. 1(2), 6.

Agusta, L., \& Sutanto, E. M. (2013). Pengaruh Pelatihan dan Motivasi Kerja Terhadap Kinerja Karyawan CV. Haragon Surabaya. Agora, 1, No. 3.

Fauzan, R., Indrasary, Y., \& Muthia, N. (2018). Sistem Pendukung Keputusan Penerimaan Beasiswa Bidik Misi di POLIBAN dengan Metode SAW Berbasis Web. Jurnal Online Informatika, 2(2), 79. https://doi.org/10.15575/join.v2i2.101 
Huda, M., \& Komputer, B. (2010). Membuat Aplikasi Database Dengan Java MySql dan NetBeans. Elex Media Komputindo.

Kadir, A. (2014). Pengenalan Sistem Informasi Edisi Revisi. Andi.

Kawistara, P. H. (2017). Pemograman Web. Informatika Bandung.

Khozaimi, Ach, et al. Sales Quality Determination Using Simple Additive Weighting (SAW) and Analytical Hirarki Process (AHP) Methods. Jurnal Ilmiah Kursor, 2020, 10.2: 95-100.

Kusumadewi, S., Hartati, S., Harjoko, A., \& Wardoyo, R. (2016). Fuzzy Multi Attribute Decision Making (Fuzzy Madm). Graha Ilmu.

Limbong, T., \& Iskandar, A. (2020). Sistem Pendukung Keputusan: Metode \& Implementasi.

Nasri, E., \& Kania. (2019). Rekayasa Perangkat Lunak Seleksi Penentuan Vendor Jasa Tenaga Kerja Dengan Metode SAW. 3(2), 13.

Nofriansyah, D. (2015). Konsep Data Mining Vs Sistem Pendukung Keputusan. Deepublish.

Rachmad, A., Syakur, M. A., Widjaya, E., Pramudita, Y. D., Anamisa, D. R., Putro, S. S., ... \& Purwanti, E. (2019). The selection of new students RSBI using fuzzy SAW based application. no. December.

Rochman, E., Hidayatullah, S., Syakur, M., Khozaimi, A., Jauhari, A., Pramudita, Y., \& Rachmad, A. (2018). Decision Support System of Poor Community Category in Sampang District using AHP (Analytical Hierarchy Process). In Proceedings of the 1st International Conference on Computer Science and Engineering Technology Universitas Muria Kudus. doi (Vol. 10).

Saputra, A. (2012). Sistem Informasi Nilai Akademik untuk-Panduan Skripsi. Elex Media Komputindo.

Shalahudin, M., \& Rosa, A. S. (2018). Rekayasa Perangkat Lunak (Terstruktur dan Berorientasi Objek) Edisi Revisi. Penerbit Informatika.

Susan, E. (2019). Manajemen Sumber Daya Manusia. Adaara: Jurnal Manajemen Pendidikan Islam, 9(2), 11.

Zabar, A. A., \& Novianto, F. (2015). Keamanan HTTP dan HTTPS Berbasis WEB Memggunakan Sistem Operasi Kali LINUX. Komputa : Jurnal Ilmiah Komputer dan Informatika, 4(2), 69-74 